Bridgewater State University

2012

\title{
Telling Stories About Indigeneity and Canadian Sport: The Spectacular Cree and Ojibway Indian Hockey Barnstorming Tour of North America, 1928
}

Andrew Holman

Bridgewater State University, a2holman@bridgew.edu

\section{Virtual Commons Citation}

Holman, Andrew (2012). Telling Stories About Indigeneity and Canadian Sport: The Spectacular Cree and Ojibway Indian Hockey Barnstorming Tour of North America, 1928. In History Faculty Publications. Paper 31.

Available at: http://vc.bridgew.edu/history_fac/31 


\title{
Telling Stories About Indigeneity and Canadian Sport: The Spectacular Cree and Ojibway Indian Hockey Barnstorming Tour of North America, 1928
}

\author{
Andrew C. Holman \\ Bridgewater State University
}

Filed away in the archives of the City of Toronto, Canada, are two photographs from the winter of 1928 that capture a peculiar moment in the histories of North American sport and race relations. The first of these shows 16 Native Canadians divided into two teams dressed in ice hockey gear, buckskin jerseys, and feathered headdresses. The teams are assembled along one side of a chartered bus (equipped with chained tires), which was parked in front of the Ontario Provincial Legislature and festooned with a sign announcing the "Cree \& Ojibway Indian Hockey Tour" (Figure 1). The second image captures the two teams assembled at an outdoor stadium in Toronto-a warm spell in mid-January having melted the outdoor ice and leaving the hockey players standing in slush (Figure 2). These pictures are at once compelling and puzzling because they compress a bundle of images and understandings of the Native past. They demand explanation. What was the Cree \& Ojibway Indian Hockey Tour? What did it mean? This essay, a study in the cultural history of sport and race in North America, focuses on a rare moment when sporting events became forums for racial imposture and counterfeiting. Racial mimicry has been the subject of a good deal of recent scholarly focus among social and cultural historians, most of it addressing stock caricatures, such as blackface minstrelsy and the Indian "dress up" cultures of campfire girls and fraternal orders. ${ }^{1}$ The Cree \& Ojibway Indian Hockey Tour belongs to a different order still. And unpacking its meaning is akin to pulling the loose bit of yarn on an old sweater: the more one pulls, the more the fabric unravels, and the more we appreciate how complex the construction was in the first place.

Between December 1927 and February 1928, 18 hockey-playing members of the Cree and Ojibway First Nations in northeastern Ontario undertook a celebrated barnstorming tour of 22 cities and towns in Canada and the United States. Traveling by charter bus, the "Cree \& Ojibway Indian Hockey Tour" was a well-promoted and cleverly planned road trip that began in Timmins, Ontario, and swung through southern Ontario before it crossed the U.S. border and performed in Michigan, Ohio, Pennsylvania, New York, Connecticut, Rhode Island, and Massachusetts. In 


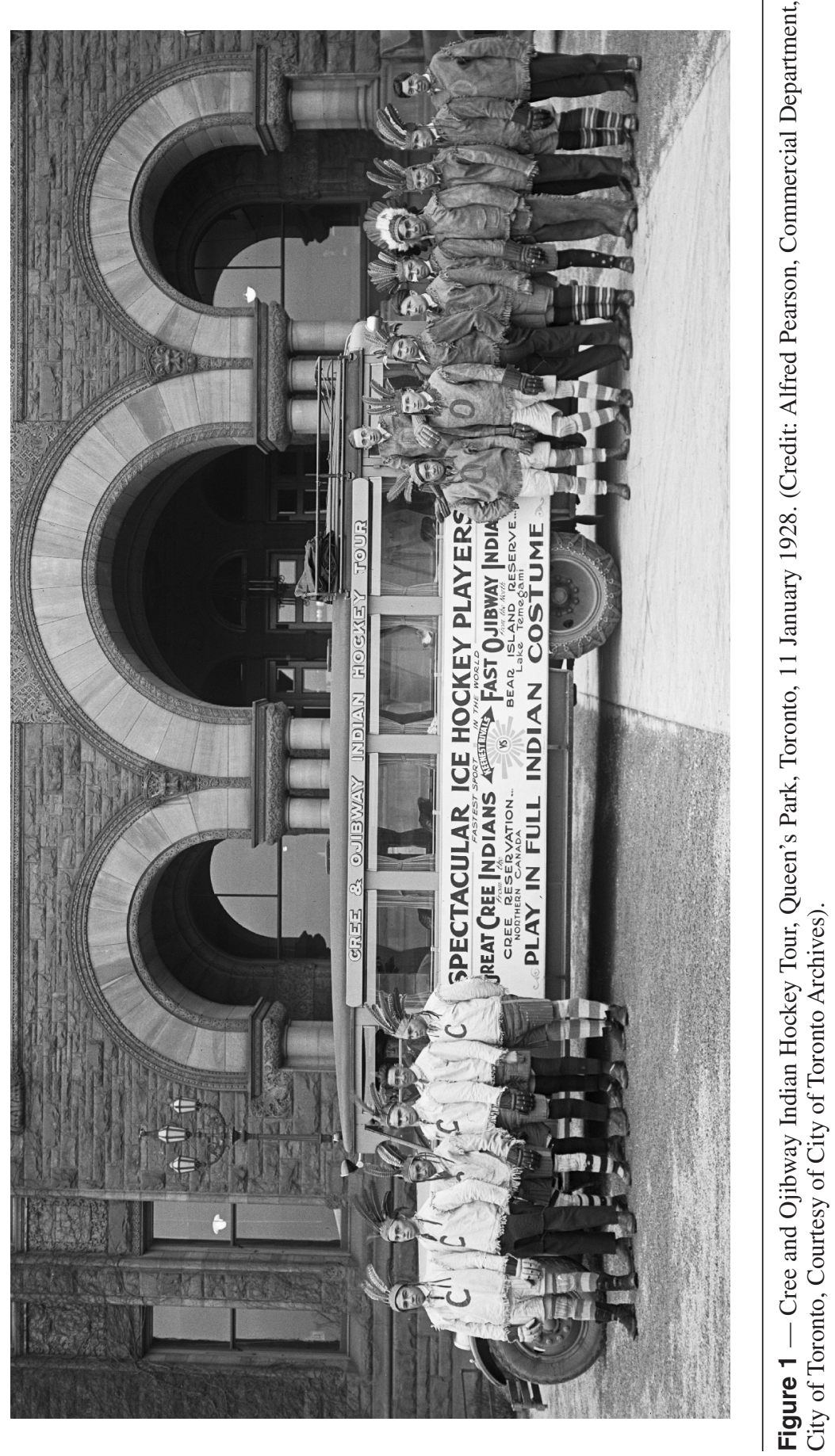




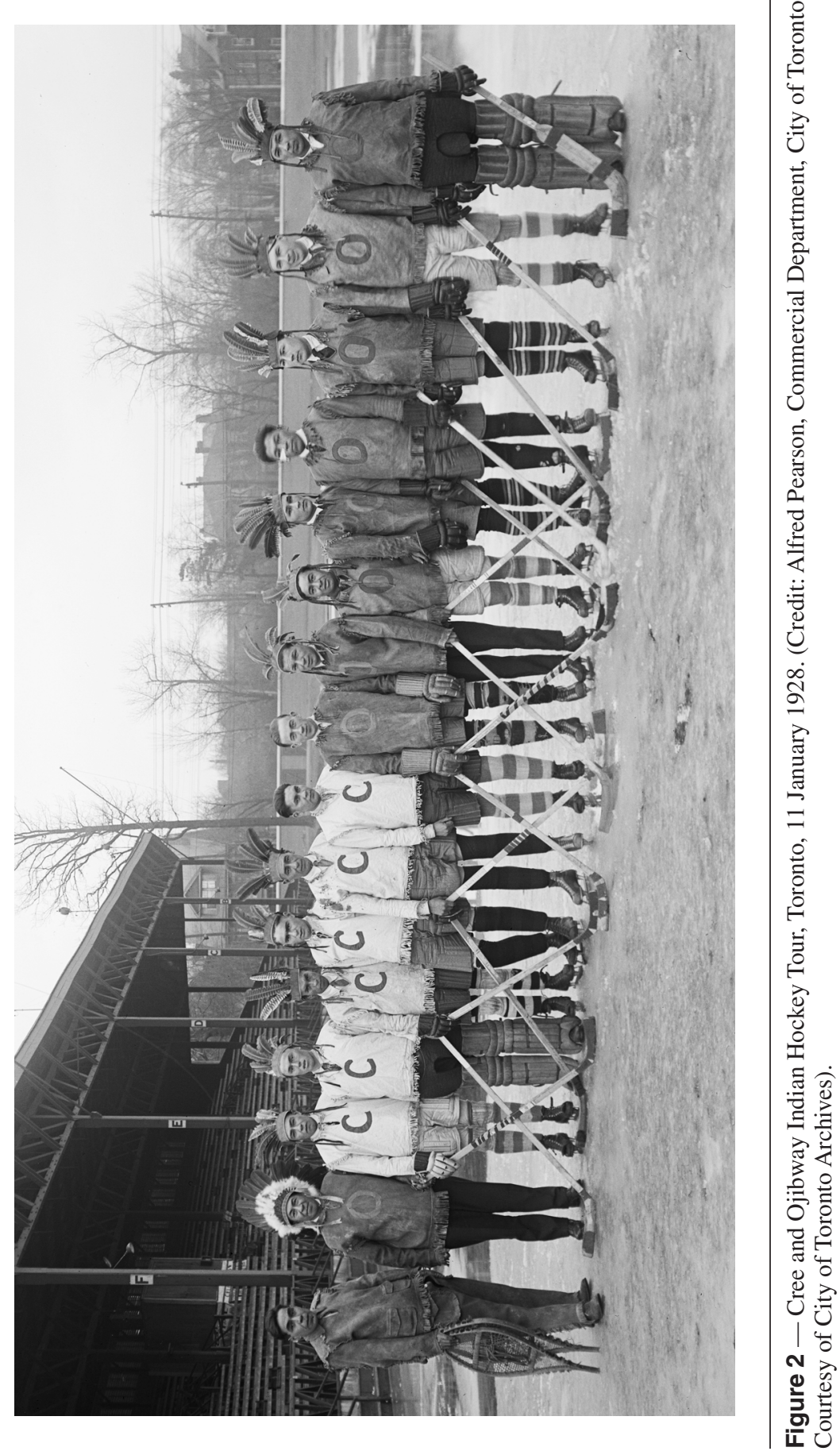


some cities, the players divided themselves into two "tribes," the Crees versus the Ojibways, and billed their games as part of a series for the "Indian Hockey Championship of Canada." In other locations, only one team was put on the ice to face a local side. But in every place, the Native teams wore buckskin jerseys with fringe and (in pregame warm-up) ceremonial headdresses made of feathers. Invariably, the pregame hype oversold the real product that the Natives put on the ice, but the spectacle was more important than the quality of the hockey played, for this tour was unique. While barnstorming was a frequent feature of American baseball and football in the 1920s and 1930s and, as Don Morrow and Kevin Wamsley have each demonstrated, though celebrated Canadian lacrosse tours to Britain were undertaken in the 1870 s and 80 s, these sorts of excursions were rarely done in hockey. ${ }^{2}$ Moreover, though individual First Nations players were sprinkled through amateur and minor-pro hockey in these years, hockey teams made up wholly of Natives were virtually unknown.

In almost every city they visited, the Cree and Ojibway games were received generously (though not uncritically) by the local press. Pre- and postgame articles were sometimes lengthy and detailed and accompanied by photographs. Still, there was remarkable variation in the stories. As Michael Oriard has written about early football coverage in the U.S., the early twentieth-century press did much more than merely report the facts of sports matches. To sell newspapers, writers created a variety of narrative plots that taught audiences to "read sports as powerful cultural texts." 3 Newspaper coverage of sporting events was a form of popular drama that emphasized dominant cultural myths. Even the dullest game could be imbued with meanings drawn from tensions of modern life (science vs. brawn; order vs. chaos; civilized vs. savage). There are many angles to the story of the "Cree \& Ojibway Indian Hockey Tour," but perhaps the most fascinating one involves its popular representation in the press. ${ }^{4}$ Reportage on the Cree and Ojibway games can be read as a commentary on commerce and sport, authenticity and authority, and power and powerlessness in First Nations-white relations in 1920s North America.

Sportswriters created three alternative (and sometimes competing) narratives to tell the story of the Cree-Ojibway hockey games. First, hockey was described as an authentically indigenous game, a sport first played by northern Natives that was now being reappropriated in this colorful tour. Headdresses, buckskin jerseys, and invented players' names (e.g., "Tomahawk") confirmed the Aboriginal nature of the game. The story of these games was the story of a game played in its pristine form. A second narrative contrasted with this one. In some locations, the Indian barnstorming tour was cast as a clever exercise in modern enterprise. These Natives (all of whom were reportedly summer fishing guides in northern Ontario camps) used new technology in communications to sell to southern Ontarians and Americans their "products": hockey and northern tourism. Finally, some sportswriters saw the tour for what some of the players must have believed it to be-a subversive self-parody, a drama of racial mockery and power inversion. In dressing up and acting as "imaginary Indians," these real Natives were having a laugh at their paying customers' expense.

First, perhaps some context is in order. By the early 1920s, the world of ice hockey had come a long way from its origins as a gentleman's pastime played by white, privileged male students from McGill University in mid-1870s Montreal. ${ }^{5}$ After a decade of incremental growth and change in the 1880s, hockey exploded 
in popularity in the 1890 s and became a truly national phenomenon in Canada. Published rules and equipment were spread across Canada by players, promoters, and the press in the decades before the Great War. As sport historian Alan Metcalfe wrote in his seminal study, Canada Learns to Play, "by 1905, hockey leagues had become a permanent part of the Canadian winters. . . Hockey pervaded the whole country." " Moreover, the game quickly jumped the international border and became, by the mid-1920s, an important winter spectacle in large northern U.S. cities, homes to intercollegiate teams made up of local boys as well as professional squads composed of Canadian expatriates. Commerce fueled hockey's expansion in the U.S.; by 1929, in hockey's premier professional circuit—-the National Hockey League (NHL) — six of the league's ten teams were located in U.S. cities. ${ }^{7}$ Hockey had assumed a modern form characterized by standardized rules and league constitutions, distinctive equipment, reliance upon technology (for artificial ice), and the use of "scientific" strategy by coaches and captains. The game had become ordered into an organizational pyramid - a hierarchy of authority that privileged professional hockey and sorted out the cascading ranks of amateur leagues and teams, from national to local, from senior "A" to children's play. The system was both integrated and readily understandable to all: by the 1920 s, big daily newspapers, such as Toronto's Globe, the Montreal Star, and the New York Times, published the scores and gossip from even the most remote corners of the hockey world. A fan in Vancouver, for example, could easily follow the fortunes of his favorite senior hockey team, be it in Truro, Nova Scotia, at Harvard University in Boston, in the Montreal City League, or virtually anywhere else. ${ }^{8}$

For all of this remarkable change, one of the most unmistakable cultural features of the sport had not changed at all since its founding: color. Hockey was still essentially a white game. Modern hockey was developed in the house of amateurism, an elite, gentlemanly ideal that assumed whiteness. Amateur codes of sporting bodies all across the Anglo-American world in the late nineteenth century were prescriptions of proper behavior though not for everyone in society—only for their own kind. ${ }^{9}$ Comparatively few nonwhites played the game and no singular nonwhite athlete challenged the racial profile of the amateur ideal. In its first five decades, hockey lacked a Jim Thorpe, a Jack Johnson, or a Tom Longboat - a nonwhite athlete so undeniably proficient that the sport's whiteness needed to be questioned or qualified. ${ }^{10}$

Of course, some nonwhites did play hockey in Canada and the United States in the game's early days and though good players, they were far from being the game's recognized "stars." In Minnesota, pioneering multi-sport black athlete Bobby Marshall excelled as a cover point for the semiprofessional Minneapolis Wanderers from 1907 to 1909; known for his scoring and occasional rough play, he was, the Minneapolis Journal noted in January 1907, "one of the best players in the city."11 Similarly, Woodstock's Bill "Hippo" Galloway and Stratford's Charlie Lightfoot were African Canadians who appeared for their respective town teams in Ontario Hockey Association play in the 1890s and 1900s. ${ }^{12}$ Even more significant, as Garth Vaughan and the brothers Darril and George Fosty have documented, black Nova Scotians were playing competitive hockey on segregated teams as early as 1895 for the celebrated "Coloured Hockey Championship of Canada."13

First Nations hockey in these years leaves a fainter trace. There must have been Natives who played on eastern hockey teams before 1930 without ever having had 
their race identified in the public record, but the ones we do know about are few in number. One rare example is Kahnewake Mohawk Paul Jacobs—one of the many famed bridge-building Mohawk "skywalkers" of the early twentieth century-who excelled as a player for the Dominion Bridge Company and Laval University teams in the Montreal City League and with New Haven and Cleveland of the U.S. Amateur Hockey Association in the years 1912 to $1922 .{ }^{14}$ Even fewer documents reveal hockey teams composed wholly or predominantly of Natives, those that represented Indian Reserves or predominantly Native locations. One example is the Dunbow School Hockey Club, an Indian Residential School whose teams in 1898 and 1899 impressed observers by defeating neighboring white teams. A photograph of the 1899 team reproduced in Gary Zeman's book Alberta on Ice reveals eight fully uniformed and equipped native hockey players (and one white), straight-faced, shorn, and groomed to look like proper Canadian gentlemen, and accompanied by their coach, the Roman Catholic priest Oblate Father Albert Naessens, who was bestowed the title "Father of Native Hockey in Alberta" by contemporary Albertans owing to the masterful play of his charges. ${ }^{15}$

Whether on segregated or integrated teams, when blacks and Indians did play hockey, they introduced a kind of contrast, or relief, that pushed contemporary observers to confirm the game's whiteness. Black and Indian skaters were marginalized on the ice and off, exceptions that existed dramatically to prove the rule, and were acceptable as long as they were in the minority, subordinate, and not a serious challenge to hockey's early social order. ${ }^{16}$ Race mattered in early hockey. Whiteness was one of its principal hegemonic practices. In this light, the "Cree \& Ojibway Indian Hockey Tour" becomes even more interesting.

\section{The Tour}

The Cree and Ojibway Indian Hockey Tour of 1927-28 must have been grueling for its participants (Table 1). On the road for a little more than two months, these young men visited 22 towns and cities, playing 18 games of hockey and traversing over 1700 miles on winter roads. The organizers of the tour were two Ojibway brothers from Temagami, Ontario-William and Joe Friday - to whom fell the work of recruiting players, booking transportation and accommodation, and arranging and scheduling hockey matches. The tour included huge American metropolises, such as Philadelphia and Boston, as well as tiny Ontario towns, such as Longford Mills and Blenheim, and several medium-sized cities in between. ${ }^{17}$ The teams performed in front of both large audiences and small gatherings. If press reports can be believed, the teams skated in front of a capacity crowd of 5,000 at Cleveland's Elysium, 2,000 at the New Haven Arena, 1,200 at Springfield's West Side Arena, and 3,000 at Philadelphia's Arena. ${ }^{18}$ When they were not on the ice (and when local YMCAs and service clubs afforded them time and space), these Natives performed in specially orchestrated "powwows"- demonstrations of canoe paddling, bow-and-arrow whittling and shooting, birch-bark canoe construction, moose calling, and snowshoe making. They even demonstrated dog-sleigh techniques using a harness, a sled, and the one sled dog they brought with them on the journey. In these events, they displayed "authentic" artifacts, too: a tepee, axes, tomahawks, arrowheads, animal skins, and stuffed fish. "Motion pictures" showing northern 


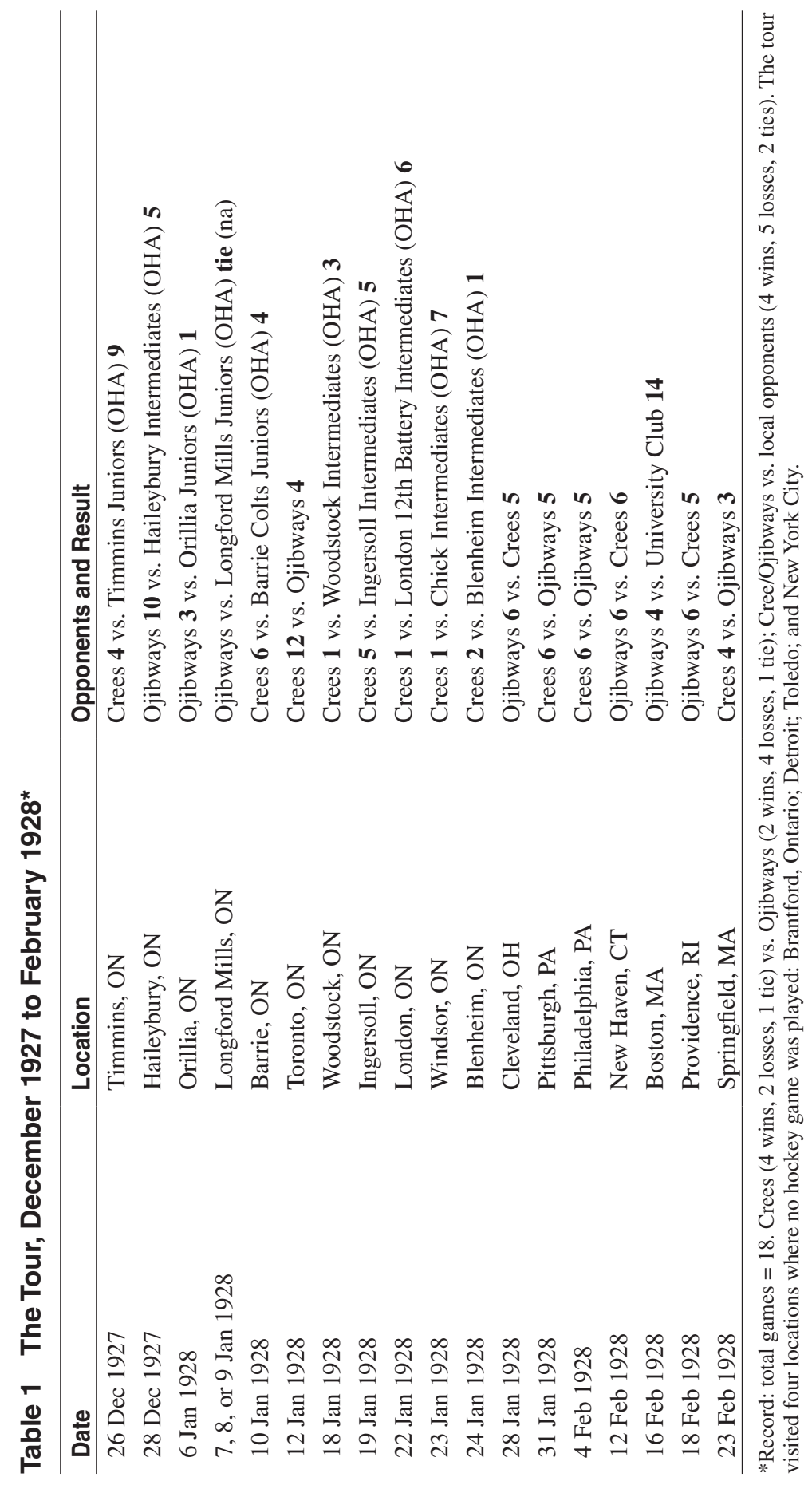


wildlife rounded out the presentation. For all this, the Friday brothers charged patrons a small admission fee at the door: 15 cents for an afternoon performance, 25 cents in the evening. ${ }^{19}$ In Orillia, the editor of the Packet and Times invited all to come out to the YMCA, "where the history and traditions of the Objibways [sic] will be unfolded." ${ }^{20}$ Wherever they could arrange it, the teams quartered at YMCA facilities as well (perhaps for no greater a charge than they earned from staging their powwows). ${ }^{21}$

Though the press characterized them as a monolithic collection of "full-blooded Indians from the North," this description papered over a more complex reality. Though evidence is lacking for a complete prosopography, available sources reveal that the players came from a variety of backgrounds. Many of them were born to two native parents, but their English or French surnames point to a mixed-blood heritage common to many in the areas of the Canadian north where Northwest Company and Hudson's Bay Company (HBC) fur traders had operated since the late 1700s. Most of them came from one of two places: the Cree community in Chapleau, northeast of Sault Ste Marie, or the Bear Island Ojibway community in Temagami, north of North Bay. The division seen sometimes on the ice-Cree vs. Ojibway-had very little real meaning. In northeastern Ontario, Cree and Ojibway natives were often intermarried and many families considered themselves virtually one people: Anishinaabe. There, by the 1920s, much of whatever ancient tribal division that had existed was virtually erased by the homogenizing influences of integrated railway and road travel, the residential school experience, and the effect that an insatiable demand for summer tourist guides had in encouraging native families in the region to work together. ${ }^{22}$ But the players were differentiated by other demographic factors. They were (at least nominally) Roman Catholics and Anglicans (in seemingly equal measure), and they ranged in age considerably.

A few examples illustrate these characteristics (see Table 2). Albert Petrant, a 20-year-old goaltender and Benjamin McKenzie, a 21-year-old forward, were raised in Catholic households by Ojibway parents who earned their livings as winter hunters and summer guides in Temagami. Twenty-year-old George Turner lived in the household of his "uncle," John Turner Jr, a Bear Island tour camp proprietor and son of a well-known and influential HBC factor. The fleet George Pishabo — son the Temagami Ojibway chief, William Pishabo-was 19 years old. Among the older players was Alec "Snitch" McAuley, the team's star center and goal scorer, a 27-year-old Cree, born to two Cree parents from Chapleau. George "Farmer" Linklater was 29 years old, a veteran of World War I, and according to the 1911 Canadian census, the son of a white Anglican father and a Native mother from White River Village west of Chapleau. According to his family's genealogical website, Chapleau's Cecil Corston was of mixed blood, a product of the HBC fur trade in the region. ${ }^{23}$

Though they came from rather remote places in the Ontario northland, these players were not recent converts to the game. Hockey had sunk its roots quickly and deeply in northeastern Ontario and by the early 1900s local cultures of the game flourished. ${ }^{24}$ But how talented these players really were is hard to say. The teams did not have consistent lineups from game to game, and some Native players were clearly better than others. ${ }^{25}$ It is difficult to draw much from hyped-up press reports or even the game scores. The overall tour record shows that the Crees bested the Ojibways (four wins, two losses, one tie), making them the ostensible winners 


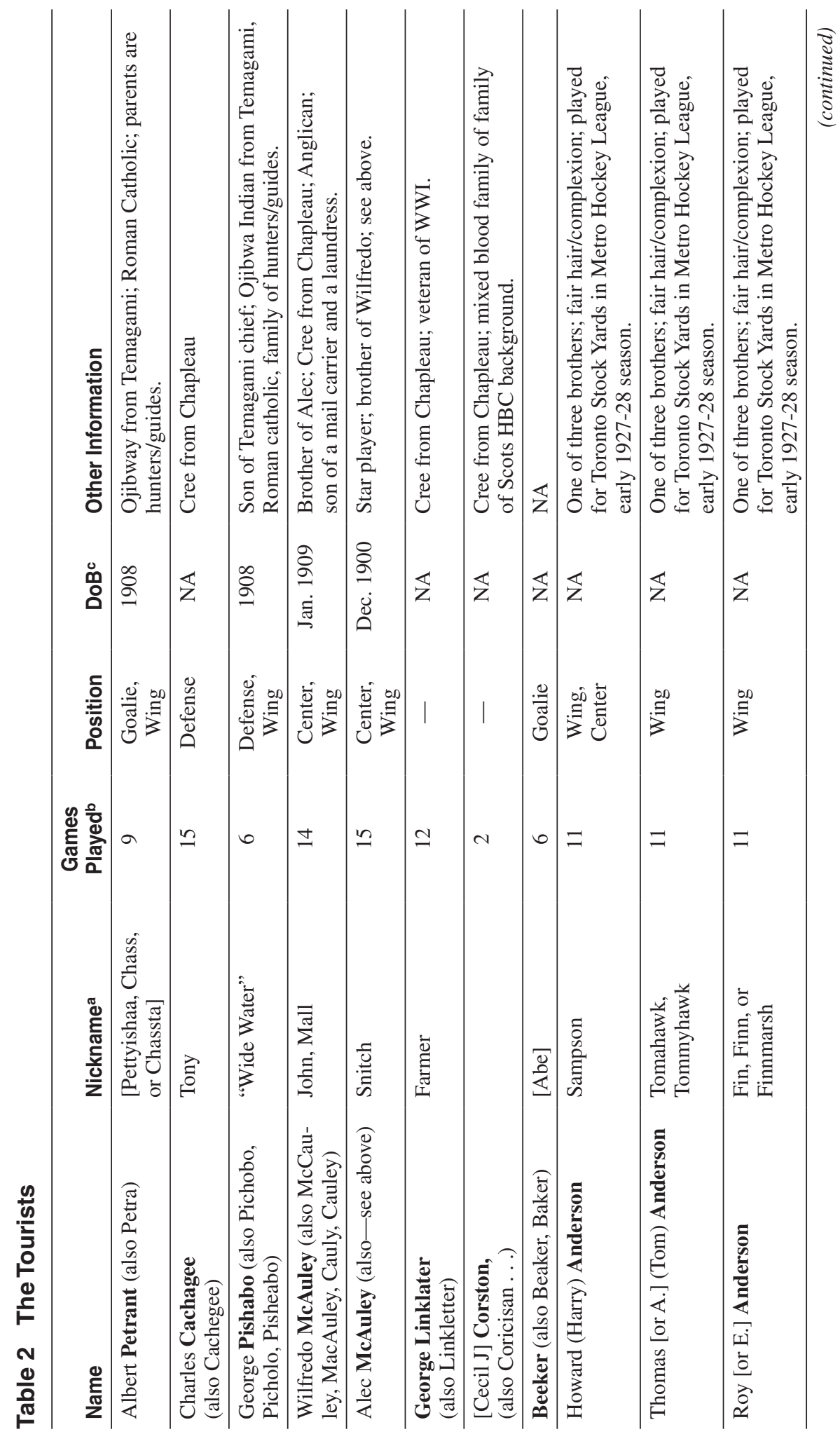




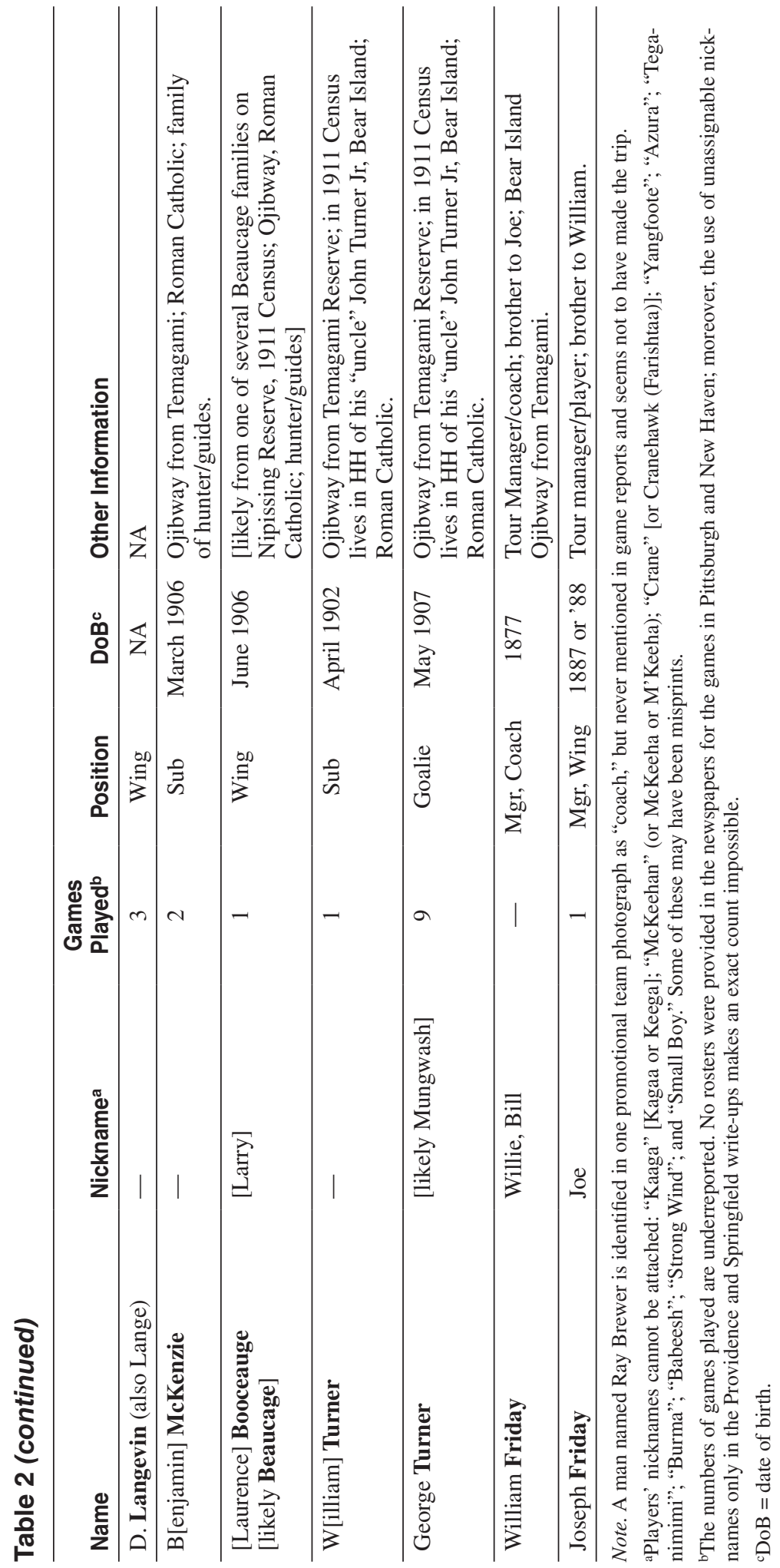


of the "Indian Hockey Championship of Canada." ${ }^{26}$ Against local opponents, the Indians (appearing alternately as "Crees" and "Ojibways" posted a marginally losing record (four wins, five losses, two ties). In some games, the Crees or Ojibways played against younger junior teams (16-19 years) and lost (Timmins); in other games, they fared well against tested and competitive intermediate Ontario Hockey Association (OHA) teams (Ingersoll). Clearly, their play did not match the pregame hype, and sometimes they were not competitive at all (London, Windsor). In Boston, they suffered their most embarrassing defeat to a collection of former American collegiate stars and George Owen, a Canadian-born ex-Harvard standout and former NHL-er with the Boston Bruins. ${ }^{27}$ And yet, in the end, the scores seemed to matter less than the spectacle.

The Cree \& Ojibway Indian Hockey Tour would have meant much less had it not been for the role that the daily press played in advertising the coming of the tour, reporting the matches, and bestowing meaning on them. By the 1920s, sport reports had ceased to be simple, factual, stolid accounts of who played, when and where, and with what result. Hockey and other games were portrayed thickly and with drama; they were canvasses on which heroes and villains, favorites and underdogs, authorities, rule breakers, and subversives were cast and recast. Every game was a live stage play just waiting to be invested with meaning. ${ }^{28}$ The Cree \& Ojibway Indian Hockey Tour happened at a time when a new, dramatic formula for reporting sports news could make an already colorful story sensational. Here, when they reported the coming and going of this tour, the press spun three distinct (though sometimes conflicting and overlapping) narratives, each of which revealed a telling "truth."

\section{Hockey as Authentic Native Culture}

It must have been impossible for sportswriters to pass up the narrative that was handed to them by the appearance of 18 Natives clad in buckskin and feathered headdresses. The Cree and Ojibway teams screamed "Wild West," or a contact tale in the style of James Fenimore Cooper. Their hockey matches were screens on which the obvious Indian War metaphor could be splashed out replete with references to raiding parties, scalping, and Native "savagery." Colorful headlines, subheadings, and leads all used that language, and both pregame notices and postgame reports gushed with hackneyed metaphors. On 19 January 1928, the Windsor Star announced that "From the pine-clad . . . shores of old lake Temagami, a feathercrested tribe of Cree redskins will sweep into the Border Cities Monday night to do battle with the Windsor Chicks hockey brigade on the local Arena's ice surface. The Indians from the north are touring the Dominion and expect to collect a few scalps on their Windsor stop." About a month later, a Boston Globe headline raised expectations with the same language: "Indian Sextet from the Far North Will Seek Scalp of University Club Here Tonight." In Pittsburgh, one editor forecasted bad blood in the coming Cree-Ojibway game: "... their enmity on the ice is reminiscent of the days when the tribes battled with tomahawks and arrows." 29

Even more vivid themes were employed in postgame write-ups throughout the tour. "With hockey sticks instead of war clubs, and skates in place of moccasins, and puck in lieu of arrows," the Orillia Packet and Times announced on 12 January 1928, "the touring Indian tribe of Objibways [sic] put the Orillia junior 
O.H.A. team to the rout, with a total of three scalps to one." In Windsor, "Indians, real Indians, swept down on this border settlement yesterday but they came by motor bus instead of pony and they carried hockey sticks instead of tomahawks. At midnight, after an hour of battle, the paleface remained supreme in hockey." And in Philadelphia, each "brave battl[ed] with the stoic pertinacity of his race for victory. The ice was dotted with Redskins as the Indians wielding their sticks in tomahawk fashion sliced each other to the ice. . . The battle had the color of a primitive combat staged upon a natural river rink in Northern Canada." Even Toronto's quality newspaper, The Globe, could not resist the temptation. Reporting on the tour from afar, one 16 February 1928 sports page headline read: "Boston University Club Scalps Indian Hockeyists." 30

Much of this discourse consciously overdid it and merely borrowed from the jargon that sportswriters had used for some time to describe the feats of white sporting teams that had adopted ethnic nicknames. In the 1910s, Toronto's Globe often referred to the professional Montreal Canadiens as the "fleet French" and the St Michael's College OHA and Toronto St Patricks (National Hockey Association) teams as the "tough" Irish, as though these monikers would enlighten their largely Protestant and wholly anglophone readers, or help them decide for whom they should cheer. ${ }^{31}$

In all of this colorful commentary, in all of this "humor," there was a morethan-subtle assertion that Indian hockey was authentic hockey, and that these teams provided glimpse of the modern sport's ancient forebears. In the late nineteenth century, as Michael Robidoux has observed effectively, hockey's ties to aboriginal sport were played up by contemporaries; its close resemblance to lacrosse and its hyper-physicality reinforced the idealized "images of masculinity valued in First Nations culture." 32 White sportsmen, reporters, and promoters wanted to believe that Native hockey possessed authenticity of a sort that white hockey did not or could not claim. When they played it, Natives played the original game. ${ }^{33}$ Having an ancient root bestowed a sense of nobility on the game that few other contemporary big-time sports could claim. The Cleveland News waxed nostalgic about this fiction in its pregame announcement:

Canada is the home of hockey and the Indians of that country were the first to play it. At the outset the game was but a rude affair, as compared to the way it is played today, and the number of participants on a side was unlimited. It was taken up by the French and English settlers of the Dominion and gradually developed into the king of winter sports. The Canadian Indians never lost their love for the sport and many of them are skillful players, although the number engaged in professional hockey is very small. But far up in the North woods, they play in their villages, on the ice of lakes and streams. Two full-blooded Indian teams will appear on the Elysium ice Saturday night in the only hockey game scheduled for Cleveland this winter. One team is composed of Crees and the other of Ojibways. ${ }^{34}$

A Barrie, Ontario, editor's pitch was less poetic but complementary in tone: "the famous Cree Indian hockey team from Bear Island will be in Barrie on Tuesday next. .. . It will be worth while to come out . . . to see these Indians play real hockey." "The Indians [are the] originators of ice hockey," the Philadelphia Inquirer's writer noted after the Cree-Ojibway contest there; "[they] gave a great display of how to 
play the game." 35 In taking this line, newspapermen cultivated a public curiosity about the exotic culture of Natives and painted the games as the chance see real Indian culture unveiled. Moreover, the presence of renowned Native athletes at some of these games helped to prove their authenticity. Natives who had made it in the white sporting world had come to bear witness to a well-kept secret. In Toronto, the Cree-Ojibway contest was made legitimate, in part, by the presence of Tom Longboat, an "interested spectator [who] lent much vocal encouragement to the battle." In Springfield, the proof was even better - the game was refereed by Henry "Buddy" Maracle, the "real Redskin of the champion Springfield Indians of the Canadian-American League" and a former resident of northeastern Ontario. ${ }^{36}$

Essential to the notion of Indian hockey as authentic was the players' claim as amateur sportsmen. Despite the ascendancy of the NHL in the 1920s, and the presence of openly professional hockey in the U.S. and Canada since 1904, amateurs and professionals coexisted uneasily. Powerful amateur organizations such as the Ontario Hockey Association insisted that professionalism had sullied the game and, in an attempt to protect its reputation, ruled that any player who had ever taken pay for play or even played against professionals would forfeit his amateur status. ${ }^{37}$ Real hockey was not played by hired guns. "The full-blooded Indian hockey teams . . . are real amateur aggregations," the Providence Journal assured its readers. "Although these Redskins are such skilled players that some professional teams would like to take their pick of the collection, it is said that they cannot be enticed to leave the amateur ranks. Money and civilization mean little to these aborigines, who live close to nature in the Canadian wilds." 38

Convinced of (or at least curious about the prospect for) Native hockey authenticity, reporters seemed to look for a distinctive Indian style of hockey, one that had demonstrable differences from the game played by local white boys. Recent scholarship in sport history tells us that hockey had become branded by the 1920s; by this date, a number of rival versions of the game had, through fusion and competition, become one version, "THE" game of hockey. As Stephen Hardy and Bruce Kidd have noted, real, modern hockey by the 1920 s contained three essential ingredients - speed, science (or combination play), and mayhem (that is, acceptable, routine violence in the form of bodychecking). Modern hockey was measured by players and teams that used these elements effectively. ${ }^{39}$ There was some variation in what reporters saw in the Cree and Ojibway style, but most reporters opined that it lacked one or more of the essential elements of the modern game. Indian hockey was fast at times and skillful at others, but they generally demonstrated a version of the sport that had long been left behind in white sporting circles.

Cree and Ojibway players were congratulated widely in the press for their persistence and determination on the ice. They were complimented as "hardy" and "tireless skaters," and "hard to hurt and untiring." Press reports focused on the play of particularly impressive players, like Pishabo and Alec McCauley, who had "both endurance and speed as well as the eye of an eagle." In Ingersoll, the "men of the North [played] with their characteristic aggressiveness. . . . They checked like they ride the rapids. They fought their way along as they would 'mush' countless miles along the trap lines." Excellent skaters, the Cleveland Plain Dealer asserted, the Indians are also "adept at stick handling and masters of the poke check." These comments are a small sample of the positive observations made by news writers who watched the tour, but they reveal a broader common thread. The 
most impressive parts of Indian hockey were the separate talents—speed, aggressiveness, tirelessness, stick handling, and stick checking — that individual players brought to the rink. ${ }^{40}$

Where Indian hockey was judged more harshly and found wanting was in the other traits that made hockey a modern game according to contemporaries: scientific strategy, or combination, and violence..$^{41}$ Indian hockey was impressively fast, but too individual and not very physical. Indian hockey had not progressed much past shinny, an early, disorganized "pickup" version of the game that paled in comparison to its sophisticated, scientific successor. A full-column write-up on the Cree-Woodstock Intermediates game in mid-January 1928 spelled out this contrast. "The game was interesting all the way through," the Sentinel Review reporter noted, "because it was a demonstration of the old and new styles of hockey." The Crees surprised the Woodstonians by playing three forwards in the Woodstock defensive zone, attacking at all times, and frustrating efforts to develop combinations plays (or "breakouts"). But for all its flash, their style-individual aggressiveness - did not give them much of chance to demonstrate "clear-cut" hockey. "They showed all the way through the contest all kinds of speed and an uncanny method of holding the puck and getting their shots away fast from almost any angle." In the end, Woodstock won 3-1, the reporter concluded, by virtue of its combination play. ${ }^{42}$ Though the hockey reporter for the Cleveland Plain Dealer may have been less steeped in hockey culture than his counterpart in Woodstock, he drew a similar conclusion when the Ojibways trimmed the Crees 6-5 in the Elysium. "Combination play was very conspicuous by its absence, but what was lacking in this department was more than made up by the earnestness with which the players went about their duties." In Windsor, it was "superior combination" that made the local side "the superior aggregation" and led to the local intermediate team-the "Chicks"- to win 7-1 over the Crees. "The Chicks found that they could both outspeed and outguess the rearguard." The headline writer for the Border Cities Star was even more to the point than the article's reporter (as headline writers usually are): "Crees Lack System . .."43 Finally, despite impressive size, these Indians played the game in a remarkably placid, nonphysical style, a trait that belied the overblown promotional Wild West discourse. Several reporters were impressed by these men as physical specimens, but dismayed that they were so unwilling to use their size to advantage. Game reports repeatedly observed that the Indians played a "clean" game. A writer for the Providence Journal told audience members to expect "little or no body checking." 44

It would be easy to dismiss as speculative the idea that these reporters invented an Indian style of hockey (and superimposed it on the Crees and Ojibways) if the same sort of musing had not gone on in other sports. But it did. As Michael Oriard as shown, American football writers developed their own implicit ethnic and racial taxonomy in the years between 1920 and 1950. The tactical style of the 1920s Haskell (Kansas) Indian Institute teams carried out was routinely described as "colorful," "wily," "crafty," and "tricky." By the 1950s, some football writers began to ponder the existence of a black athletic aesthetic, a theme that has since been exploited by commentators on weekly game telecasts and by NFL Films. ${ }^{45}$ Even in hockey today, pundits put forth the imagined construct of a European style of hockey. Though it is impossible for us to know exactly what the hockey reporters of the day saw when they looked at the Cree-Ojibway games, it is clear that they 
were seeking a way to make sense of it through their writing. Their observations, repeated in a broad variety of far-flung daily newspapers, reveal a search for racial order in the hockey world, an order that celebrated the white game as modern and progressive and the Indian game as archaic and quaint, a "vanishing" style played by a "vanishing" people.

\section{Barnstorming for Bucks: Hockey and Northern Tourism}

How the Cree-Ojibway hockey tour was first conceived is not documented, but it is not difficult to imagine how it came to be. It was a business decision made by the two entrepreneurial Friday brothers from Temagami, "Willie" and Joe. The Fridays were shrewd promoters; they had to be to run a tour that required a great deal of planning, a knowledge of the market for this "product," and an extensive network of contacts. The costs would have been daunting: a Gray Line charter bus (and driver) for two months' travel; accommodations in 22 locations for 19 men; and money for meals. The Fridays would have had to strike deals with a long list of arena owners and managers for ice use (and perhaps gate receipts) in an era when the bottom line-as hockey historians Stephen Hardy, and Bruce Kidd and John Macfarlane have argued-trumped all other considerations for ice arena owners. ${ }^{46}$ This could not have been an excursion run by inexperienced or unconnected promoters.

The Friday family was no stranger to commerce, and no stranger to strangers. A prominent and widely known group of hunter/guides, the Fridays of Bear Island, Temagami, were at the forefront among Native families who took advantage of a changing economy. A growing tourist trade-among wealthy Canadian and American summer excursionists, campers, anglers, and hunters - in the early twentieth century provided great opportunity for Natives to break their reliance on trapping furs for sale to the Hudson's Bay Company. By World War I, some families did well enough as guides in the summer months that winter trapping (and sporadic attempts at farming) became a decidedly secondary source of income. ${ }^{47}$ Wealthy tourists to northeastern Ontario sought the northern experience-wilderness and the pursuit of fish and game in the company of a real Native guide who would be companionate but subordinate, quiet and not overly familiar. Native guides in Temagami and others parts of New Ontario were happy to oblige and cash in, especially as the increased use of the automobile and printed tourist literature in the 1920s brought more and more wealthy Canadians and Americans to the north. "Travel books, guidebooks and other promotional materials provided lists of reliable guides by name," historian Patricia Jasen notes, ". . . such as the Friday family at Temagami." One writer in a 1906 sportsman's magazine, Rod \& Gun in Canada, wrote: "An integral part of Lake Temagami-Canada's newest and loveliest holiday land-is the Friday family, a worthy family with Indian blood. . . . [The wise tourist] will close a contract with one of the Friday boys to be his guide, philosopher, friend, fisherman, canoeist, cook and tentmate." 48

The Fridays had earned a reputation as reliable, trustworthy, honest, and friendly men, but apparently they were also shrewd. There is a telling (and no doubt embellished) story in a 1910 issue of A.W. Shaw's publication System: The Magazine of Business that features "Willie" Friday and makes this point. In a short 
piece called "Grasping the Opportunity," Shaw recounts that story of Harry Charlton, publicity agent for the Grand Trunk Railroad, who sought to make his company's exhibit at the 1909 Sportsman's Show in New York more authentic by having a real Indian on hand. To that end, he arranged for Willie Friday, Temagami hunter, guide, and steamship captain, to make the long trip to the big city. Because Friday's train was reportedly late, Charlton missed him at the Jersey station, which set off in him a feeling of minor panic: "the poor, primitive, inexperienced Indian boy was nowhere in sight." What Charlton later discovered was that Friday had arrived earlier, made his own way to his host's hotel, and secured his own room key; Willie was sitting in Charlton's easy chair "contentedly smoking" when he returned. The charge for Friday's cab from the Jersey station, the host later discovered, had been neatly put on Charlton's bill and signed in Charlton's name. ${ }^{49}$

The reality of this story is impossible to measure, but the message rings true. The contact experience between Northern Ontario Natives and southern white travelers was a two-way street. The exchange between tourist and guide included more than forest knowledge for cash. Native guides like the Fridays grew to know a great deal about their wealthy tourist charges - their families, friends, and backgrounds and the places they came from. Calculating businessmen, good hunting and fishing guides could develop a tidy network of ready-made contacts if ever they left the northland and wished to use them for personal or commercial ends. And, it seems, they did. At least some sports reporters understood the Cree \& Ojibway Indian Hockey tour to be a unique, collective promotional junket-a trade mission of sorts-designed to build and maintain a well-heeled clientele for these northern hunting and fishing guides.

The Cree and Ojibway hockey tour was effectively promoted in advance and widely reported after the fact. Announcements for the tour's coming games appeared in the local press up to a week ahead of time and team photos of the Crees and Ojibways were circulated and appeared repeatedly (in whole or in edited pieces) in the advance press, described by cutlines such as "Play Here Tonight" or "These Braves Will Ride the Warpath Here Monday." 50 No press releases from the tour survive, but the language of the advance press is repetitive and indicates that some sort of prepared copy must have been sent to reporters ahead of time. And, perhaps, afterwards. The scores of the tour games were reported in the "Hockey Results" lists in a good many of the Canadian dailies, whether the Indians had played locally or not. ${ }^{51}$ Someone sent on the news.

In a few locations, press reports recognized the network of local contacts on which the Fridays leaned for logistical support and for patronage. Pilots of this excursion, the Fridays were hardly flying blind. Among the hockey crowd at the Elysium, for example, the Cleveland Plain Dealer expected to see the "travelers who have been led through the Canadian wilderness by these same players, [who] will be present to see their former guides in action. . . . Among the Clevelanders who have been guided by these men are W.C. Dunlap, ex-president of the Cleveland Athletic Club; J.C. Royon, vice president of the Union Trust Co.; A.R. Horr, vice president of the Cleveland Trust Co.; W.C. Boyle, Esq., James R. Garfield, Speedy Rush, Frank M. Cobb, W.E. Crofut." 52 The editor continued: "Hundreds of Clevelanders who are known as devotees of the great outdoors have known Willie Friday in his role as a north woods guide." ${ }^{3}$ The Fridays must have had the same sorts of contacts in other tour locations as well. In Providence, William Friday's 
commercial success was a matter for comment in the Journal, recognition by the press that these tourists were real businessmen. "The tour is also a big adventure for the manager, who is an Ojibway Indian. He is said to be a millionaire and owns a summer resort in Canada . . . is now profiting from the Ojibway silver mines. ${ }^{54}$ It is not likely that the Fridays — or any of these natives - made much money from the trip beyond covering expenses, but this was hardly a sightseeing excursion. The reward was a host of connections that these hunter/guides made and renewed with sportsmen in southern Ontario and the United States, who continued to bring their families and their wallets to northeastern Ontario when summer came.

\section{Playing Indian}

The third and final theme that emerges in the press coverage of this barnstorming tour was more subtle, but more powerful. Some sports writers and editors cut through the easily delivered, romantic Wild West discourse and recognized a more oblique and subversive message. Some newspaper writers expressed their doubts about the earnestness and authenticity of this tour and recognized what at least some of the members of the Crees and Ojibways must have thought about this twomonth "play." Though not wholly a sham or a ruse, these Natives were engaging in a table-turning exercise, using the popular cultural idea of noble savage to their own advantage and having fun at their paying customers' expense. Their willingness and ability to do that reveals a good deal about the places whence they came.

By the 1920s, northeastern Ontario had long been a racial borderland in both literal and figurative senses. In the early twentieth century, it was at once a boundary where native tribes from two different watersheds met; a zone of contact where white traders and native trappers converged; and a frontier where old, commercial, and industrializing Ontario abutted the mineral- and timber-rich quarry of New Ontario. Like all boundary regions, this borderland was a place of indeterminate, fluid, and changeable identities, where residents and visitors in each generation could define and reinvent themselves. ${ }^{55}$ It was a place where white HBC traders could "go Indian" and a place where full-blooded Natives went by such names as Roy Anderson, Alec McCauley, and Laurence Beaucage. ${ }^{56}$ Here, race was a pliable construct, and racial difference did not carry the form or function that it did in "civilization." "Race" did not have to mean white power and red (or other "colored") powerlessness; quite often it meant the reverse. In the isolated wilderness, after all, who was more powerful—white tourist or red guide? As such, race hierarchy—as it was known in other places_-was subject to inversion and racial identities were subject to alteration and playful re-invention.

Natives from Temagami and Biscotasing (near Chapleau) were hardly strangers to the idea and practice of racial imposture. After all, Canada's most famous racial counterfeit, Archie Belaney, had lived among them for some time. Belaney, or "Grey Owl," as he renamed himself, was a white English-born alcoholic genius who lived in Temagami from 1907 to 1911, married an Ojibwa woman (Angèle Belaney), and fathered a girl (Agnes) while living as a member of his father-in-law's household. In 1911, he disappeared, abandoning them both and moved west to the Chapleau District, later remarrying (twice). When, after nearly two decades of living in the borderlands, Belaney presented himself to the world in 1930 as Grey Owl, wildlife 
advocate and articulator of Canada's first forest conservation movement, it must have been a surprise to his Native family and friends in Temagami and Biscotasing. Belaney's ruse was not revealed until after he died of exhaustion following a British lecture tour in 1938. But as his biographer Donald Smith notes, even though a good many Natives knew his real identity, they decided-from love for him and admiration for his message — not to expose him. "Canadians with Indian ancestry in the 1930s simply had no incentive to declare it." 57 Within ten years, Grey Owl rose to stardom in the literary world and on the public lecture circuit. His great fame in Britain and the United States could not have been missed by real Natives in Temagami and elsewhere. And if Archie Belaney could play around with race and win and if he could use the guise of indigeneity to hoodwink people (albeit for a good cause), why couldn't real Indians do it, too?

In fact, Joe Friday had himself already become a minor celebrity on the American YMCA circuit playing Indian in the mid-1920s. Friday's adventure with the YMCA has been retold on countless local YMCA web pages that trot out the history of the "Father and Son Y-Indian Guide" program. The story relates the meeting of Friday with Harold Keltner, the director of the St. Louis YMCA sometime in the early 1920s, when Keltner was a summer tourist in Temagami. Keltner had injured his thumb whilst canoeing. Joe and his wife, Eva, a white nurse from Buffalo, were able to give him aid, and the men subsequently struck up a friendship. In their interactions, Friday allegedly said to Keltner how odd it seemed that in Native society, boys were guided principally by their fathers, while in white society, boys were raised by their mothers. The thought stuck with Keltner and inspired him to propose a YMCA program that promoted structured Native-motifed father-son (and later, mother-daughter) activities, to build that bond. In 1926 and 1927, Keltner brought Friday to Missouri to lecture to fathers and sons and to act as a counselor at the YMCA's Camp Niantic. The program relied heavily on invented tradition, "Indian" terminology, and unadulterated romantic bunkum. Everywhere he went, Joe Friday was trotted out as the inspiration for the program and its "founding father." After Friday's death in Toronto and interment in Temagami in 1955, Keltner and the Y honored Friday by marking his grave with a handsome headstone that recognizes his contribution to the movement. ${ }^{58}$ In 1970 , Keltner wrote down his recollections of their first meeting and work in a document that National Longhouse (successor to the Y-Indian Guide program) still features on its website, called "How We Found Joe Friday" (as if he had been lost)..$^{59}$ The point here is simple. Like his brother Willie's experience at the 1909 New York City Sportsman's Show, Joe Friday's interactions with Keltner and the Y-Guides must have opened up to him a world of possibilities, perhaps entrepreneurial ones. It may have been his experience as a widely recruited and well-traveled YMCA speaker in 1926-27 that helped convince Willie and him that they could put on and pull off such an extensive North American tour. ${ }^{60}$

On the tour, Cree and Ojibway players seemed to have had a great deal of fun with their image and the resonance that it developed in the southern press. In Canada, the Crees and Ojibways used their Christian names, but as soon as they crossed the border, they went almost wholly by nicknames-either real translations of their native family names or more often ones wholly fabricated for the trip-Indian alter egos. "Wide Water" and "Great Wind" fit the first category; Tomahawk, Mungwash, 
Cranehawk, Babeesh, and Kaaga fit the latter. The Press ate it up-in Cleveland, the Plain Dealer printed photos of Friday's leading players - all of them with only one-word nicknames to identify them (Figure 3).

Not all newspapermen were so lazy or gullible that they were willing to rubber stamp the Wild West narrative without at least a raised eyebrow, or a note of discomfort. It was important that some of these writers let their readers know

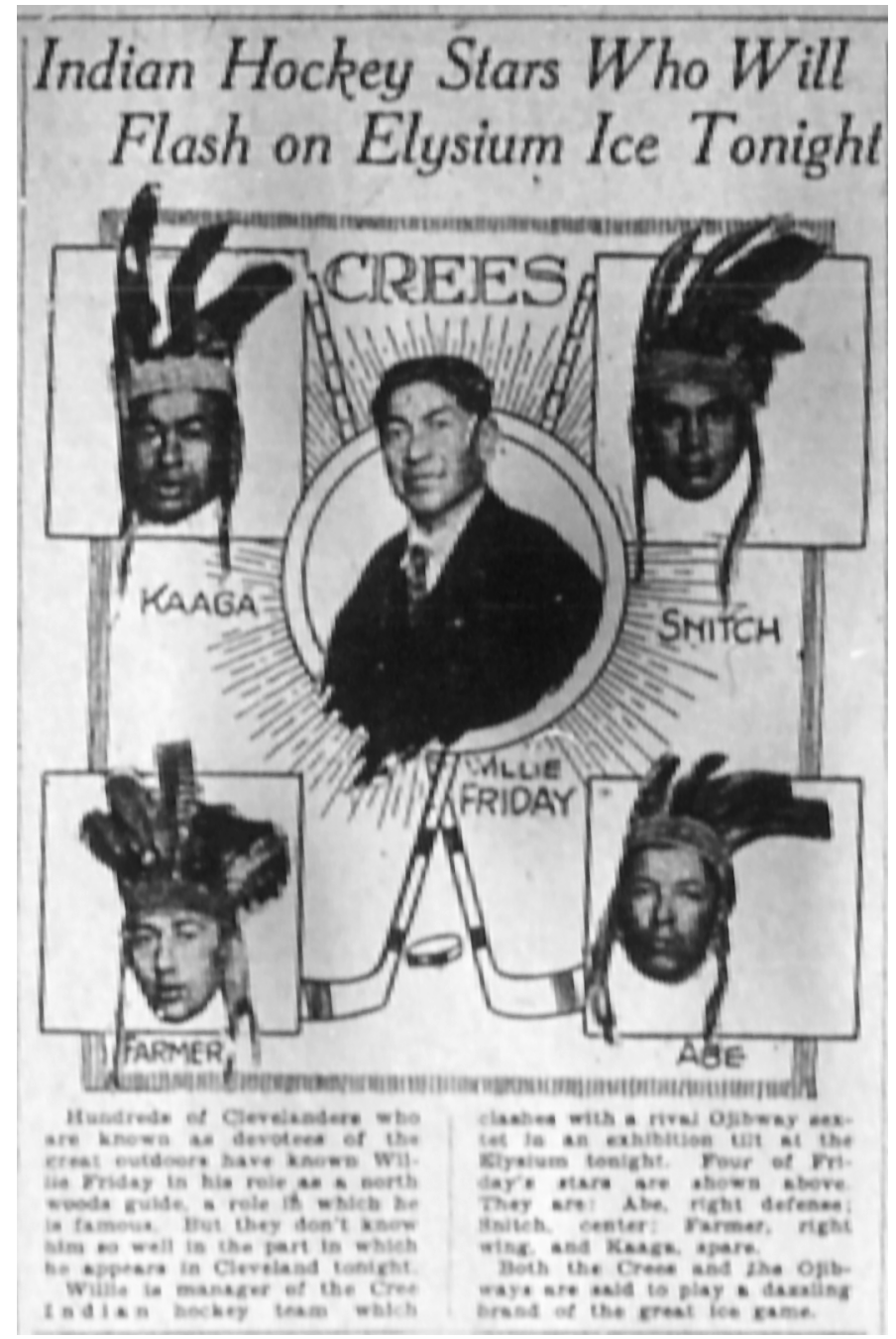

Figure 3 - Coverage in the Cleveland Press (Cleveland Plain Dealer, 28 January 1928). (Courtesy of the Ohio Historical Society). 
that the Cree \& Indian Tour was more showbiz than real artifact. These notes of incredulity were few, but telling. One Pittsburgh writer, disappointed in the quality of play in the Cree-Ojibway tilt at the Duquesne Garden labeled the match "more of a burlesque." 61 Perhaps because of earlier press accounts of the tour, a Boston Herald editor expected theater rather than sport: "on Thursday night there will be a game staged between the Ojibway Indians and the Temagami Indians [sic] from Canada." 62 It was the Herald's Stanley Woodward, however, who was most acerbic in his dismissal of the tour's use of spectacle. When the University Club drubbed the Ojibways 14-4, he saw the game as a useless farce and employed the Wild West discourse to turn the tables: the white team went "on Warpath" and "Massacred" their Indian opponents; the University Club "Aveng[ed] Custer." What is more, he went one step further and publicly cast doubt on the racial authenticity of some of the players, stating sarcastically that the Anderson brothers (three lighter-skinned Crees from Chapleau) must be "Scandinavian Indians." The performance only became acceptable for him, when the "Ojibs" "doffed the call of the wild stuff" and got down to playing real hockey. ${ }^{63}$

Though they did not convince everyone, these Indian hockey tourists played with racial stereotypes and, we can imagine, got some enjoyment out of doing it. Hockey provided them with a chance to step into American iconography and see how it felt. They hardly felt trapped by their race; by donning the feathers, they mocked those who wished them to be real authentic "Injuns"- - those who could not see them as they really were, namely, modern capitalists with a sense of humor and a flair for the dramatic. "Playing Indian" at hockey expressed a borderlander's critique of urban North America's grim determinacy about race. It was subaltern mischief making par excellence.

\section{Conclusion}

Perhaps fittingly, the Cree \& Ojibway Indian Hockey Tour ended in the same sort of murky way that it began. After their defeat in Boston, the Globe reported that the Natives would play one more game in Providence, tour New York state for two weeks, and then go home. ${ }^{64}$ But then they played one more game in Springfield, with the Republican stating that after the game was completed the two teams would split up and go "on separate trails." ${ }^{65}$ How and when they got home is unclear; what is known is that no such hockey junket was ever again undertaken.

And what can be made of all this? One must be careful about attaching too much meaning to such a singular and fleeting historical event. Still, the Cree \& Ojibway Indian Hockey Tour demands explanation. The tour was carefully organized, intricately planned, and well financed; it was deliberate. It could not have been assembled quickly or considered lightly. Through the press coverage of the Cree and Ojibway games, the tour made a statement about racial identities and sport. "Throughout a long history of Indian play," Philip Deloria writes in his pathbreaking book, Playing Indian, "native people have been present at the margins, insinuating their way into Euro-American discourse, often attempting to nudge notions of Indianness in directions they found useful. As the nineteenth and twentieth centuries unfolded, increasing numbers of Indians participated in white people's Indian play, assisting, confirming, co-opting, challenging and legitimating the 
performative tradition of aboriginal American identity." 66 So it was with the Indian hockey tourists in the winter of 1927-28. These inventive sportsmen used the press to reappropriate the popular, imaginary version of themselves, (re)asserting native presence and place in Canada's national game, promoting their own businesses and securing clientele, and subversively poking fun at the prevailing idea of "Indian" in white North America.

Finally, this tour tells us something about the centrality of myth and narrative to sports reportage, and the challenge for historians to decipher the tales that sports writers have, for a long time, projected onto their renderings of sporting events. In the Cree \& Ojibway Indian Hockey Tour, the rink was a two-way screen. Even while the Fridays and their recruits attempted to use their hockey spectacle and the press to sell themselves to prospective customers, sportswriters used the occasion to fashion their own reading of the events, and in predictable ways. In each city, and in each game, Cree and Ojibway hockey was itself a prompt for a larger discourse about identity: who Natives had become in the popular mind of the 1920s cast alongside (and against) who they wished to be. These telling stories draw into sharp relief the broader concept of sport-as-text. They put paid to the quaint notion that athletic events can ever be "only a game," benign and bereft of spin or happening in a contextual vacuum, and they push us as historians to look even more closely at other ways in which contemporary cultural discourse determines our understandings - past and present—of the games we play and watch.

\section{Acknowledgments}

This essay was originally presented at the "When Indians Play Indian" Symposium held at Texas Tech University in October 2009. Thanks to the event's co-conveners, Ethan Schmidt and Ron McCoy, for their comments on an earlier version of the essay. Thanks, too, to CART at Bridgewater State for funding support, and to Bill Newbigging, for his careful read of an earlier draft.

\section{Notes}

1. See, for example, Eric Lott, Love and Theft: Blackface Minstrelsy and the American Working Class (New York: Oxford University Press, 1995); Daniel Francis, The Imaginary Indian: the Image of the Indian in Canadian Culture (Vancouver: Arsenal Pulp Press, 1992); Philip J. Deloria, Playing Indian (New Haven: Yale University Press, 1998); Alan Trachtenberg, Shades of Hiawatha: Staging Indians, Making Americans, 1880-1930 (New York: Hill \& Wang, 2004); Sharon Wall, 'Totem Poles, Tepees, and Token Traditions: 'Playing Indian' at Ontario Summer Camps, 1920-1955" Canadian Historical Review 86, 3 (September 2005) 513-44 and Michael D. McNally, "The Indian Passion Play: Contesting the Real Indian in Song of Hiawatha Pageants, 1901-1965," American Quarterly, 58, 1 (2006) 105-36.

2. Don Morrow, "The Canadian Image Abroad: The Great Lacrosse Tours of 1876 and 1883," Fifth Canadian Symposium of the History of Sport and Physical Education (Toronto, 1982) 11-23; Kevin B. Wamsley, "Nineteenth Century Sport Tours, State Formation, and Canadian Foreign Policy" Sporting Traditions 13, 2 (May 1997) 73-89.

3. Michael Oriard, Reading Football: How the Popular Press Created an American Spectacle (Chapel Hill: University of North Carolina Press, 1993) 89. 
4. One wonders what these games meant to the participants themselves. Alas, no archival records survive that provide clues to how these Indians who "played Indian" felt about it.

5. The birth of the modern game of hockey has been the subject of considerable debate. Though several claims have been made, it is fair to say that the great majority of scholarly historians of Canadian sport agree that the modern game was born when James Creighton and his classmates played the first games of hockey at the Victoria Skating Rink in Montreal in 1875 and became a recognized sport when its rules were first published in the Montreal Gazette in 1877. That said, ball-and-stick games on and off the ice had been played in Europe and among Natives in North America for centuries before the "Montreal game" was born. See J.W. Fitsell, Hockey's Captains, Colonels \& Kings (Erin, ON: The Boston Mills Press, 1986) 31-52; Richard Gruneau and David Whitson, Hockey Night in Canada: Sport, Identities and Cultural Politics (Toronto: Garamond Press, 1993), ch. 2.

6. Alan Metcalfe, Canada Learns to Play: The Emergence of Organized Sport, 1807-1914 (Toronto: McClelland \& Stewart, 1987) 64, 73.

7. On hockey's American “invasion," see Stephen Hardy, “Long Before Orr: Placing Hockey in Boston, 1897-1929" in Randy Roberts, ed. The Rock, The Curse, and the Hub: A Random History of Boston Sports (Cambridge: Harvard University Press, 2005) 245-72; Hardy, "Memory, Performance, and History: The Making of American Ice Hockey at St. Paul's School, 1860-1915" International Journal of the History of Sport, 14, 1 (1995), 97-115 and Andrew C. Holman, "Playing in the Neutral Zone: Meanings and Uses of Ice Hockey in the Canada-U.S. Borderlands, 1895-1915" American Review of Canadian Studies 34, 1 (Spring 2004), 33-57.

8. This theme is visible in Bruce Kidd, The Struggle for Canadian Sport (Toronto: University of Toronto Press, 1993) ch. 5; John Chi-Kit Wong, Lords of the Rinks: The Emergence of the National Hockey League (Toronto: University of Toronto Press, 2005); and Stacy Lorenz, “'In the Field of Sport at Home and Abroad': Sports Coverage in Canadian Daily Newspapers, 18501914" Sport History Review 34, 2 (2003) 133-67.

9. On the equation of amateurism with whiteness, see Don Morrow and Kevin B. Wamsley, Sport in Canada: A History (Toronto: Oxford University Press, 2005) 70, 72-72.

10. See Gerald R. Gems, "The Construction, Negotiation, and Transformation of Racial Identity in American Football: A Study of Native and African Americans" American Indian Culture and Research Journal 22, 2 (1998) 131-50; Geoffrey C. Ward, Unforgivable Blackness: The Rise and Fall of Jack Johnson (New York: Knopf, 2004); and Bruce Kidd, "In Defence of Tom Longboat" Canadian Journal of History of Sport 14, 1 (1983) 34-63.

11. Minneapolis Journal, 26 January 1907, cited in Steve R. Hoffbeck, "Bobby Marshall: Pioneering African American Athlete, Minnesota History 59, 4 (2004) 168.

12. Frank Cosentino, Afros, Aboriginals and Amateur Sport in Pre World War One Canada, Canadian Historical Association (Canadian Ethnic Group Series) Booklet No. 26 (Ottawa: CHA, 1998), 9. By 1900, at least seven black teams were played on Maritime ice, notable almost as much for their colorful names as for their color: the Dartmouth Jubilees, Amherst Royals, Truro Victorias, Africville Seasides, Halifax Eurekas, and Charlottetown's West End Rangers; 56 men in all. These teams made up the misnamed "Colored Hockey League," a series of challenge matches that filled out winter seasons between 1900 and 1905.

13. The league and its memory has become celebrated recently in Fostys's documentary film (and book of the same title) Black Ice. See www.blackicebook.com. Accessed 22 May 2012.

14. James Milks, "Paul Jacobs: First Native Canadian in the NHL?" in Milks, ed. Pucklore: The Hockey Research Anthology Vol. 1 (Toronto: Fox Music Books, 2010).

15. Gary Zeman, Alberta on Ice (Edmonton: Westweb Press, 1985) 9. 
16. One (Toronto) Globe article in December 1927 reported the existence of "the only all-Indian hockey league anywhere," the Caughnawaga League on the "Indian Reservation" near Montreal. See Frederick Wilson, "Scanning the Sport Field," The Globe (Toronto), 22 December 1927, p. 6, cols. 3-4. On First Nations hockey history in Canada, see Robert Pitter, "Racialization and Hockey in Canada: From Personal Troubles to a Canadian Challenge" in David Whitson and Richard Gruneau, eds, Artificial Ice: Hockey, Culture and Commerce (Scarborough, Ont: Broadview, 2006), esp. 129-31. In one sense, their presence was needed by white sporting society. Hockey occasionally needed rule breakers and racial role players to remind its followers where the cultural boundaries of the sport really lay. Jim Cree, a Canadian ex-patriate who played for Syracuse and Cleveland in the old USAHA and in the New York Amateur Hockey League in the 1910s, was known widely for his rough play. See Holman, "Playing in the Neutral Zone," 38-39; John J. Hallahan, "Something New for Local Fans" Boston Globe 16 February 1928, p. 21, col. 4. It is ironic then that the Cree and Ojibway tourists of 1928 played such a nonphysical version of the game.

17. Located eight miles north of Orillia, Longford Mills had a population of 120 in 1886 and 43 in 1976. One of two reasons must have motivated the Fridays to include this location in the tour. The town lay right beside an Ojibway Indian Reserve (now Mnjikaning First Nation) and just a couple of miles from Geneva Park, a grand YMCA Camp on Lake Couchiching where the tourists may have been able to stay. Florence Ellen Carter, Place Names of Ontario Vol. One (London, Ont.: Phelps Publishing Company, 1984) 676; "Geneva Park: the YMCA's National Leadership Training Centre" www.ymca.ca. Accessed 22 May 2012.

18. "Indians Arrive" Pittsburgh Post-Gazette, 30 January 1928, p. 14, col. 8; New Haven Journal-Courier, 13 February 1928, p. 8, col. 6; "Indian Hockey Teams Turn Deaf Ear to Pro Offers" Providence Journal, 14 February 1928, p. 8, col. 5. "Redskins Provide an Interesting Puck Exhibition at Arena" Springfield Union, 24 February 1928, p. 25, col. 2. "Crees, Seemingly Beaten, Rise and Defeat Ojibways," Philadelphia Inquirer, 5 February 1928, p. S1, col. 6. There could not have been very many spectators in places such as Timmins, Haileybury, Blenheim, or Longford Mills. The rinks' capacities for spectators would not have allowed it. In some places, audiences just stayed away. Stormy weather kept the crowd size small in Providence, and in Boston, fans were-one local reporter concluded-just plain uninterested, despite the advance press there that played up the first-ever appearance of an all-Indian team in that place. "[T]he crowd was so sparse that the players had to shin over the rail after the puck when it went in the crowd." Stanley Woodward, "University Club Goes on Warpath and Massacres Indian Sextet, 14-4" Boston Herald, 17 February 1928, p. 12, cols. 1-2. See "Ojibways Nose Out Opponents at Rink" Providence Journal, 19 February 1928, p. B1, col. 2; "Clubmen Tackle Ojibway Sextet" Boston Herald, 16 February 1928, p. 12, col. 6; John J. Hallahan, "Something New For Local Fans," Boston Globe, 16 February 1928, p. 21, col. 4.

19. "Indian Pow-Wow" Brantford Expositor 14 January 1928, p. 19, col. 6; "Indian 'Pow Wow': Drew Big Crowd. Y.M.C.A. Was Scene of a Big Gathering Last Evening" Brantford Expositor, 17 January 1928, p. 8, col. 4; "The Indian Pow-Wow" The Packet and Times (Orillia), 12 January 1928, p. 12, col. 3. A similar event was held in London. See "Indian Sextet Here Saturday" London Free Press, 18 January 1928, p. 14, col. 2. In Woodstock, the group displayed its wares at the YMCA as well in the front window of a local hardware store, and planned to show its films in the public school and Collegiate Institute. "Postpone Exhibition Game," London Free Press, 16 January 1928, p. 10, col. 6; "Cree Hockeyists Play on Thursday, Woodstock Sentinel Review, 18 January 1928, p. 3, col. 4. In Springfield, they brought the Pow-Wow to the rink, demonstrating sled-dog technique and tepee building between periods. See "Indian Hockey Teams Play Here Thursday," Springfield Republican, 21 February 1928, p. 14, col. 3. 


\section{0. [Editorial], The Packet and Times (Orillia), 5 January 1928, p. 12, col.2.}

21. The teams were reported to have bunked in at the Brantford, Ontario, Y.M.C.A., for example, and at Pittsburgh's "Northside Y.M.C.A." See "Indians Arrive" Pittsburgh Post-Gazette, 30 January 1928, p. 14 , col. 8 .

22. In 1927, the Ferguson Highway was completed, providing reliable road access to and from Temagami; Toronto could be reached by car within a day. See Bruce W. Hodgins and Jamie Benedickson, The Temagami Experience: Recreation, Resources and Aboriginal Rights in the Northern Ontario Wilderness (Toronto: University of Toronto Press, 1989) 177-78. The homogenizing experience of Indian residential schools is captured best in Basil Johnston, Indian School Days (Toronto: University of Toronto Press, 1988), a moving autobiographical account of life at St. Peter Claver Indian Residential School in Spanish, Ontario, a Roman Catholic institution where native boys from all over Ontario were placed in the 1930s and 40s. On sport in American Indian boarding schools, see John Bloom, To Show What an Indian Can Do: Sports at Native American Boarding Schools (Minneapolis: University of Minnesota Press, 2000).

23. See Fifth Census of Canada, 1911, District No. 99 (Temagami), Library and Archives of Canada, Ottawa. On Pishabo, see Hodgins and Benedickson, Temagami Experience, 211-15. On the Corston family, see Corston Family Genealogical Website, "Standing Stones: From the Orkney Isles to Chapleau" www.corstonfamily.org. Accessed 22 May 2012.

24. One of the first openly professional hockey league was the Temiskaming Hockey League, located in northeastern Ontario. See Gruneau and Whitson, Hockey Night, 75. In Chapleau, for example, residents enjoyed the use of an outdoor rink as early as the late 1880s; in 1904, reliable ice was available when the rink was fully enclosed and roofed. Early photos of Chapleau hockey teams show the old indoor rink-its ice, roof supports and artificial lighting. In 1912, seats were built over the "changing rooms and a 3 -foot wide walk along the sides and south end . . . to accommodate spectators." The building was expanded further in the 1920s, allowing for an enlargement of the ice surface and providing room for teams' benches along the east wall. George Evans, "Chapleau's Arenas" in Snapshots of Chapleau's Past, No. 5 http://chapleaulibrary.com/ gevans/5.html. See "Chapleau Hockey Team, 1905" http://chapleaulibrary.com/crichton/VC6/217. HTM and "Chapleau Hockey team circa 1906-07" http://chapleaulibrary.com/crichton/VC6/451. HTM. All sites accessed 22 May 2012.

25. In several press reports, these Indian players were championed as "famous" but this seems to have been nothing more than hype. Of these players, only the Anderson brothers seem to have gained renown for their play outside of the North. Roy and Harry Anderson would have been familiar to Toronto fans at the Ravina Rink, as Toronto's Globe noted, "having played for Stock Yards in the Mercantile League at the beginning of the present [1927-28] season until the lure of the wide open spaces proved too strong and they went back North." Globe (Toronto) 13 January 1928, p. 6, col. 7. On the tour, a few players logged much more ice time than others. See Table 2 herein, "Games Played" column. Canadian editors were generally unimpressed, an exception being one from the London Free Press who concluded that the Crees were as good as "many intermediate O.H.A. sextets." In American cities, where NHL and Canadian-American League professional action was the most readily available comparison, the play seemed "somewhat tame." See "Ingersoll Ties Indian Sextet," London Free Press, 20 January 1928, p. 17, col. 1; "Cree Indians in 4-to-3 Win Over Ojibway Rivals" Springfield Republican, 24 February 1928, p. 22 , col. 3.

26. This mantle was proclaimed in several press reports sometimes as the "Redskin" Championship of Hockey. "Indians to Stage Title Game Here," Providence Journal, 16 February 1928, p. 6 , col. 8. The press reported this series inconsistently, too. One Providence writer held that 
series pitted the Ojibways-Indian Hockey champions of "Northern Canada" against the Crees, champions for "Southern Canada." No such claims were real; and most Cree natives actually lived north and west of the Ojibways. "Indian Hockeyists Play Here Tonight," Providence Journal, 18 February 1928, p. 8, col. 2.

27. On early Boston hockey, see Hardy, "Long Before Orr" (on Owen see, 262, 267).

28. Lorenz, "'In the Field of Sport at Home and Abroad': Sports Coverage in Canadian Daily Newspapers, 1850-1914” Sport History Review 34, 2 (2003) 133-67; Lorenz, “'Bowing Down to Babe Ruth': Major League Baseball and Canadian Popular Culture, 1920-1929" Canadian Journal of History of Sport 26, 1 (1995) 22-39; Oriard, Reading Football.

29. "Cree Hockey Team Coming. Redskin Braves Play Chicks Here At Arena" Border Cities Star (Windsor), 19 January 1928, Sec. 2, p. 2, col. 4; "Indian Sextet from the Far North Will Seek Scalp of University Club Here Tonight," Boston Globe, 16 February 1928, p. 21; "Indians Arrive" Pittsburgh Post-Gazette, 30 January 1928, p. 14, col. 8.

30. Orillia Packet and Times, 12 January 1928, p. 9, col. 4; "Chicks Drub Indians, 7-1" Border Cities Star (Windsor), 24 January 1928, Sec. 2, p. 2, col. 4; Stan Baumgartner, "Crees, Seemingly Beaten, Rise and Defeat Ojibways," Philadelphia Inquirer, 5 February 1928, p. S1, col. 6, p. S4, col. 3; "Boston University Club Scalps Indian Hockeyists" The Globe (Toronto) 16 February 1928. As one might expect, the "Wild West" language was not employed when the Crees and Ojibways played games in northern Ontario, nearer their homes. There, they could not have been considered "exotic" and the language would have been considered insulting. The accounts of the Cree/Ojibway games written by correspondents in North Bay and Barrie, for example, were reported as though they were regular fixtures. See "Timmins Defeats Matagami Crees 9-4" and "Indian Six Defeat Haileybury 10 to 5," North Bay Nugget, 30 December 1927; "Indians Win on Soft Ice 6 to 4," Barrie Northern Advance, 12 January 1928, p. 1, col. 1; "Indian Hockeyists Lose to Timmins Juniors, 9-4, The Globe (Toronto), 28 December 1927, p. 6, col. 2; "Indian Team Wins by 10 to 5 In Exhibition Hockey Game" The Globe (Toronto), 30 December 1927, p. 13, col. 3. The New York Times did not stoop to employ the Wild West metaphor either; its sole account takes a rather stolid, factual tone. "Indian Sextet Defeated. Ojibways Bow to University Club of Boston, 14 to 4," New York Times, 17 February 1928, p. 17, col. 3.

31. See, for example, "St. Pats Beaten by Fleet French," The Globe (Toronto), 5 February 1920, p. 14; "Argos Confident of Beating St. Michael's" The Globe (Toronto), 2 February 1915, p. 9.

32. Michael A. Robidoux, "Imagining a Canadian Identity through Sport: A Historical Interpretation of Lacrosse and Hockey" Journal of American Folklore 115, 456 (2002) 220. This point is also ably made in his more recent piece, "Historical Interpretations of First Nations Masculinity and its Influence on Canada's Sport Heritage," The International Journal of the History of Sport, 23, 2 (March 2006) 267-84.

33. Robidoux has examined this equation in his studies of current-day aboriginal hockey, an equation often drawn by Natives themselves. "[I]n conversations that I have had with first nations men from Ontario to the Northwest Territories, the game is often claimed as their own, and a part of First Nations cultural heritage." This "reappropriation" of the game, he argues further, is visible in the tendency for today's teams from First Nations communities to adopt and claim racist "white" teams names—-such as Chiefs, Braves, or Black Hawks—and symbols and logos—such as Indian Heads or tomahawks - and make them their own. In doing so, they are not "unwittingly catering to their own subjugation," Robidoux writes. "When these images are worn by Aboriginal players, they are meaningful symbols that tie directly into their cultural heritage. ... [They] are worn with pride and become important signifiers of First Nations identity, despite their dubious origins in the professional sports industry." Robidoux, "The Subaltern Framework of Aboriginal Hockey: Gnoseology and Thinking Along the Borders" in Colin Howell, ed. Putting It on Ice Vol. I (Halifax: Gorsebrook Research Institute, 2002) 30, 32. 
34. "Where It's All Ice and Indians" copy from the Cleveland News reprinted in The Globe (Toronto) 31 January 1928, p. 10, cols. 3, 4. The Globe could hardly allow this romanticism to pass without at least a sarcastic subtitle, a dig perhaps at American ignorance of Canada.

35. Barrie Northern Advance, 5 January 1928, p. 1, col. 5; Stan Baumgartner, "Crees, Seemingly Beaten, Rise and Defeat Ojibways," Philadelphia Inquirer, 5 February 1928, p. S1, col. 6, p. S4, col. 3 .

36. "Crees Go on Rampage; Defeat Ojibways, 12-4" The Globe (Toronto), 13 January 1928, p. 6, col. 7; "Indian Hockeyists ready for Action" Providence Journal, 17 February 1928, p. 7, col. 2; "Maracle Will Handle Ojibways-Crees Game," Springfield Republican, 20 February 1928, p. 10, col. 2.

37. See Alan Metcalfe, "Power: A Case Study of the Ontario Hockey Association, 1890-1936" Journal of Sport History 19, 1 (1992) 5-25.

38. "Indian Hockey Teams Turn Deaf Ear to Pro Offers," Providence Journal, 14 February 1928, p. 8, col. 5. Three days later, the same writer noted: "The trip is largely a sightseeing tour for the Indians and their manager, William Friday, as the players are all amateurs." "Indian Hockeyists Ready for Action" Providence Journal, 17 February 1928, p. 7, col. 2. Most of these games were billed as charity matches, the proceeds benefiting a local cause. In Springfield, Massachusetts, the game was sponsored by the Springfield Kiwanis Club and its gate receipts were to be given to the city's Child Welfare Club and in Philadelphia, the game's proceeds went to the Elks' Children's Fund. See "Indian Team in West Side Game" Springfield Daily News, 23 February 1928, p. 24, col. 6; "Crees, Seemingly Beaten, Rise and Defeat Ojibways," Philadelphia Inquirer, 5 February 1928, p. S1, col. 6.

39. See Hardy, "Long Before Orr" and Kidd, Struggle for Canadian Sport, ch. 5. See also Andrew C. Holman, "Stops and Starts: Ideology, Commercialism and the Fall of American Women's Hockey in the 1920s" Journal of Sport History 32, 3 (Fall 2005) 328-50.

40. "Indian Hockeyists Ready for Action” Providence Journal, 17 February 1928, p. 7, col. 2; "Real Indians Will play Here Sunday" New Haven Journal-Courier, 8 February 1928, p. 8, col. 6; "Crees Hold the Locals to Draw" Ingersoll Daily Sentinel Review, 20 January 1928, p. 4, col. 2; "Indian Icers Play to Large Crowd," Cleveland Plain Dealer, 29 January 1928, p. B2, col. 3.

41. These were the same points of criticism made of Canadian lacrosse teams in Britain in the mid-Victorian era. See Morrow, "Canadian Image."

42. "Locals Win Fast Game from Indian Team... Indians Play in Old Style," Woodstock Sentinel Review, 19 January 1928, p. 8, col. 1. A similar message was evident in the Sentinel Review's report on the tour's game in London. See "Battery Beat Touring Indians by 6-1 Score" Woodstock Daily Sentinel Review, 23 January 1928, p. 6, col. 4.

43. "Indian Icers Play to Large Crowd," Cleveland Plain Dealer, 29 January 1928, p. B2, col. 3; "Chick Drub Indians, 7-1. Crees Lack System and Punch of Locals" Border Cities Star (Windsor), 24 January 1928, Sec. 2, p. 2, col. 4.

44. See "Ingersoll Ties Indian Sextet" London Free Press, 20 January 1928, p. 17, col. 1; "Indians to Stage Title Game Here," Providence Journal, 16 February 1928, p. 6, col. 8.

45. Michael Oriard, King Football: Sport \& Spectacle in the Golden Age of Radio \& Newsreels, Movies \& Magazines, The Weekly \& The Daily Press (Chapel Hill: University of North Carolina Press, 2001) ch. 9.

46. Hardy, "Long Before Orr"; Kidd, Struggle for Canadian Sport, ch. 5, Kidd and John Macfarlane, The Death of Hockey (Toronto: New Press, 1972); and Holman, "Stops and Starts."

47. On this transition, See Hodgins and Benedickson, Temagami Experience, chs. 3, 5, 8 , and 9 . 
48. Patricia Jasen, "Native People and the Tourist Industry in Nineteenth-Century Ontario" Journal of Canadian Studies 28, 4 (1993-94) 21.

49. "Grasping the Opportunity" in Arch Wilkinson Shaw, ed. System: The Magazine of Business XVII, 4 (April 1910) 408-9.

50. See "Indian Hockey Team Here To-Morrow" London Free Press, 20 January 1928, p. 16, cols. 4-6; "Play Here Tonight," Pittsburgh Post-Gazette, 31 January 1928, p. 17, cols. 4-6.; "These Braves Will Ride the Warpath Here Monday" Border Cities Star (Windsor) 20 January 1928, sec. 2, p. 3, cols. 2-5.; "Indian Puckmen Here Next Week" Springfield Republican, 16 February 1928, p. 16, col. 3; "Indian Team Here Friday" Woodstock Sentinel Review, 11 January 1928, p. 6, cols. 5-7; "Indians Will Be Here Tonight" Woodstock Sentinel Review, 18 January 1928, p. 6, col. 4.

51. See "Hockey Results" St. Catharines Standard, 23 January 1928, p. 7, col. 4.

52. "Indians in Ice Contest Here" Cleveland Plain Dealer, 27 January 1928, p. 18, col. 3. From the early 1900s, a large contingent of Clevelanders annually made their way to summer in Temagami and established close ties with locals. See Hodgins and Benedickson, Temagami Experience, 116-18.

53. "Indian Hockey Stars Who Will Flash on Elysium Ice Tonight" Cleveland Plain Dealer, 28 January 1928, p. 18, cols. 4-5.

54. "Indian Hockeyists Ready for Action" Providence Journal, 17 February 1928, p. 7, col. 2.

55. Jeremy Adelman and Stephen Aron, "From Borderlands to Borders: Empires, Nation-States, and the Peoples in between in North American History" American Historical Review 104, 3 (June 1999) 814-841; Evan Haefeli, "A Note on the Use of North American Borderlands" American Historical Review 104, 4 (October 1999) 1222-1225.

56. In 1929, Ontario's Surveyor General L.V. Rorke opined that the Temagami Indians were "More in touch with civilization than any other band, that they guided and explored like white men." Hodgins and Benedickson, Temagami Experience, 148.

57. Donald B. Smith, From the Land of Shadows: The Making of Grey Owl (Saskatoon: Western Producer Prairie Books, 1990) 185.

58. See "Famed Joe Friday Dies After Year of Illness," The Daily Nugget (North Bay) 12 February 1955, p. 13, cols 4-5; "The Joe Friday Biography" www.nationallonghouse.org/Archives/ History/Briefhistory.html. Accessed 22 May 2012. A great many YMCA websites still feature history sections that refer to the Y-Indian Guide program.

59. In 2003, the YMCA formally divested itself of the program, claiming that the use of native terms and imagery was offensive to Native Americans. A private Christian organization - National Longhouse - was incorporated and assumed the rights to these popular programs. See www. nationallonghouse.org/Archives/History/Briefhistory.html. Accessed 22 May 2012. More on Friday's relationship with Keltner and the YMCA can be found in Biographical Records, boxes 66 and 109, at the Kautz Family YMCA Archives, St. Louis, Missouri.

60. Beyond his Y-Guide involvement, Joe Friday had a good deal of experience in the white world outside of northeastern Ontario. At age 27, he joined WWI as a CEF volunteer in 1916, and fought in Europe. Attestation Paper No. 1006615, Enlistment Records of the Canadian Over-Seas Expeditionary Force, Library and Archives of Canada, Ottawa. Oddly, his birth date is listed on this form as 17 November 1888 and that his Religious Denomination is Anglican. He is denoted, additionally, as such: "Is full blooded Indian."

61. "Cree Indians Beat Ojibways, 6-5” Pittsburgh Post-Gazette, 1 February 1928, p. 16, col. 2.

62. Italics mine. "Indian Teams at Arena Thursday" Boston Herald, 13 February 1928, p. 8, col. 2. 
63. Stanley Woodward, "University Club Goes on Warpath and Massacres Indian Sextet, 14-4" Boston Herald, 17 February 1928, p. 12, cols 1-2.

64. See "Babe Ruth Hero of Ojibway Indians. Hockey Players Also Enjoy Baseball" Boston Globe (Evening), 17 February 1928, p. 19, col. 8.

65. Springfield Republican.

66. Deloria, Playing Indian, 8. 